\title{
Children with asymptomatic coronavirus disease-19 (COVID-19): Insights from 2-to 15-year-old cases
}

Mariella Lombardi ( $\square$ mariella.lombardi.ut@gmail.com )

University of Burgundy

Dominique Caro

University of Tours

Pascal Brett

University of Reims Champagne-Ardenne

Silvia Wiggins

University of Burgundy

Case Report

Keywords: COVID-19, SARS-CoV-2, Children

Posted Date: November 30th, 2020

DOI: https://doi.org/10.21203/rs.3.rs-115973/v1

License: (9) This work is licensed under a Creative Commons Attribution 4.0 International License.

Read Full License 


\section{Abstract}

Summary of clinical characteristics of 25 confirmed cases of COVID-19 in children aged between 2 and 15 years, with at least one infected member in their family, are reported and discussed herein. Eighteen patients are asymptomatic, and seven have mild complications without requiring mechanical ventilation or intense unit care (ICU). Results suggested that children with infected family members are very likely to be asymptomatically infected.

\section{Background}

An outbreak of coronavirus disease-19 (COVID-19) infection began in December 2019 in Wuhan, the capital of central China's Hubei province [1, 2]. Since then, COVID-19 has become a public health threat to people all over the world. The lower airway is the primary target of the infection for severe acute respiratory syndrome coronavirus 2 (SARS-CoV-2). In patients with severe COVID-19, pneumonia is always present $[3,4]$. The most common complaints of patients consist of fever $(98 \%)$, cough $(76 \%)$, dyspnea (55\%), myalgia, and fatigue (44\%) [5-10]. Reports show that COVID-19 seems to be uncommon or usually with mild symptoms in children [11-14]. At the same time, it is also reported that it occurs in children, causing moderate-to-severe respiratory illness $[15,16]$. Children do not count for a large proportion of COVID-19 infections. Children who suffer from acute myocardial injury and SARS-CoV-2 might present with another viral agent coinfection [17-20]. The clinical manifestations of pericarditis and myocarditis might range from mild nonspecific symptoms to chest pain and cardiogenic shock [21-23]. Myocarditis in children might present with flu-like symptoms, shortness of breath, tachycardia, dyspnea, nausea, decreased appetite, poor feeding, and tachypnea in infants [24-26]. Previous studies are performed within small groups of children, thus needs further investigation.

\section{Patients And Methods}

The total number of confirmed cases is 412 in Dijon until June 15, 2020, with a total number of 25 children aged between 2 and 15 years. In this study, demographics, epidemiological history, and symptoms of the 25 children are mentioned and discussed.

\section{Results}

Polymerase-chain-reaction (PCR) test and computed tomography (CT) were performed on the 25 children with at least one infected member in their family between March 20 and June 15, 2020, in Dijon. Table 1 shows the Summary of the clinical characteristics of the 25 patients. The median age of the patients was 8 (range 2 to 15). Although there were both male and female children in 23 of the 25 families, 17 of the patients were male. Both PCR and CT results were positive for all 25 patients. The CT test showed patchy ground-glass opacities (GGO) for all of them. Common clinical characteristics included fever (in two patients), cough (in five) sore throat (in one), and the other 18 patients were asymptomatic. None of the 
patients had severe complications, and they did not receive mechanical ventilation or intense unit care (ICU). Finally, all patients were discharged home without requiring hospitalization.

Table 1. Summary of the clinical characteristics of 25 children with COVID-19

\begin{tabular}{|c|c|c|c|c|c|c|c|}
\hline & & emo & raphics & Epidemiologic & & reatments & \\
\hline Patient & Sex & Age & $\begin{array}{l}\text { Symptoms } \\
\text { at onset }\end{array}$ & $\begin{array}{l}\text { Number of family } \\
\text { members infected }\end{array}$ & $\begin{array}{c}\text { Severe } \\
\text { complications }\end{array}$ & $\begin{array}{l}\text { Mechanical } \\
\text { ventilation }\end{array}$ & $\begin{array}{l}\text { Intensive } \\
\text { unit care }\end{array}$ \\
\hline 1 & $\mathrm{M}$ & 15 & None & 2 & No & No & No \\
\hline 2 & F & 13 & None & 1 & No & No & No \\
\hline 3 & $\mathrm{M}$ & 15 & Cough & 1 & No & No & No \\
\hline 4 & $\mathrm{~F}$ & 13 & None & 2 & No & No & No \\
\hline 5 & $\mathrm{M}$ & 2 & None & 1 & No & No & No \\
\hline 6 & $\mathrm{M}$ & 9 & None & 3 & No & No & No \\
\hline 7 & $\mathrm{M}$ & 9 & None & 1 & No & No & No \\
\hline 8 & $\mathrm{~F}$ & 15 & $\begin{array}{l}\text { Fever; } \\
\text { Cough }\end{array}$ & 1 & No & No & No \\
\hline 9 & $\mathrm{~F}$ & 2 & None & 1 & No & No & No \\
\hline 10 & $\mathrm{~F}$ & 8 & Cough & 2 & No & No & No \\
\hline 11 & $\mathrm{M}$ & 3 & None & 1 & No & No & No \\
\hline 12 & $\mathrm{M}$ & 15 & None & 2 & No & No & No \\
\hline 13 & $\mathrm{M}$ & 8 & Cough & 2 & No & No & No \\
\hline 14 & $\mathrm{M}$ & 10 & None & 1 & No & No & No \\
\hline 15 & $\mathrm{M}$ & 11 & None & 1 & No & No & No \\
\hline 16 & $\mathrm{~F}$ & 9 & None & 3 & No & No & No \\
\hline 17 & $\mathrm{M}$ & 14 & None & 2 & No & No & No \\
\hline 18 & M & 6 & None & 1 & No & No & No \\
\hline 19 & $\mathrm{M}$ & 4 & None & 1 & No & No & No \\
\hline 20 & $\mathrm{~F}$ & 7 & None & 1 & No & No & No \\
\hline 21 & $\mathrm{M}$ & 5 & None & 1 & No & No & No \\
\hline 22 & $\mathrm{~F}$ & 3 & Fever & 2 & No & No & No \\
\hline 23 & $\mathrm{M}$ & 5 & None & 2 & No & No & No \\
\hline 24 & $\mathrm{M}$ & 11 & $\begin{array}{l}\text { Sore } \\
\text { throat }\end{array}$ & 4 & No & No & No \\
\hline 25 & $\mathrm{M}$ & 3 & Cough & 1 & No & No & No \\
\hline
\end{tabular}

\section{Discussion}

The children in families with at least one infected member with SARS-CoV-2 are very likely to be asymptomatically infected. In this study, a sample of 25 infected families were investigated; therefore, 
this can be generalized to other infected families who have children. Infected families are recommended to monitor their children to ensure a timely diagnosis.

Children who are infected by SARS-CoV-2 develop mild complications, while severe complications are observed in adults [27-29]. The reason may be different immune responses in children, including strong innate and weaker adaptive immune responses, compared to adults. This may help them with the clearance of the virus and reduced secondary lymphocyte-mediated inflammation [30-33].

Given the number of infections reported, the number of infected children aged less than 15 was small. This may be due to a lower risk of exposure rather than resistance to infection. Because children have fewer outdoor activities and travelings, making them less likely to get the virus [34].

Seventeen of the 25 children infected are male. Given that there have been both male and female children in the families reported in this study, therefore male children might be more susceptible to COVID-19 infection than female children.

The study was limited by a small sample size, inclusion only of children in Dijon with a population of 155,114 ; therefore, it still needs further investigation.

\section{Declarations}

This study was approved by the ethics committee of Hospital Center University Dljon Bourgogne.

\section{Conflict of Interest}

The authors declare that there is no conflict of interest.

\section{References}

1. Tan W, Zhao X, Ma X, Wang W, Niu P, Xu W, et al. A novel coronavirus genome identified in a cluster of pneumonia cases-Wuhan, China 2019- 2020. China CDC Weekly. 2020;2(4):61-2.

2. Zhu N, Zhang D, Wang W, Li X, Yang B, Song J, et al. A novel coronavirus from patients with pneumonia in China, 2019. New England Journal of Medicine. 2020.

3. Lai C-C, Shih T-P, Ko W-C, Tang H-J, Hsueh P-R. Severe acute respiratory syndrome coronavirus 2 (SARS-CoV-2) and corona virus disease-2019 (COVID-19): the epidemic and the challenges. International journal of antimicrobial agents. 2020:105924.

4. Lee P-I, Hsueh P-R. Emerging threats from zoonotic coronaviruses-from SARS and MERS to 2019nCoV. Journal of Microbiology, Immunology and Infection. 2020.

5. Jiang F, Deng L, Zhang L, Cai Y, Cheung CW, Xia Z. Review of the clinical characteristics of coronavirus disease 2019 (COVID-19). Journal of General Internal Medicine. 2020:1-5.

6. Song F, Shi N, Shan F, Zhang Z, Shen J, Lu H, et al. Emerging 2019 novel coronavirus (2019-nCoV) pneumonia. Radiology. 2020;295(1):210-7. 
7. Chen L, Liu H, Liu W, Liu J, Liu K, Shang J, et al. Analysis of clinical features of 29 patients with 2019 novel coronavirus pneumonia. Zhonghua jie he he hu xi za zhi= Zhonghua jiehe he huxi zazhi= Chinese journal of tuberculosis and respiratory diseases. 2020;43:E005-E.

8. Lechien JR, Chiesa-Estomba CM, De Siati DR, Horoi M, Le Bon SD, Rodriguez A, et al. Olfactory and gustatory dysfunctions as a clinical presentation of mild-to-moderate forms of the coronavirus disease (COVID-19): a multicenter European study. European Archives of Oto-Rhino-Laryngology. 2020:1-11.

9. Carfi A, Bernabei R, Landi F. Persistent symptoms in patients after acute COVID-19. Jama. 2020;324(6):603-5.

10. Jin X, Lian J-S, Hu J-H, Gao J, Zheng L, Zhang Y-M, et al. Epidemiological, clinical and virological characteristics of 74 cases of coronavirus-infected disease 2019 (COVID-19) with gastrointestinal symptoms. Gut. 2020;69(6):1002-9.

11. Wang D, Hu B, Hu C, Zhu F, Liu X, Zhang J, et al. Clinical characteristics of 138 hospitalized patients with 2019 novel coronavirus-infected pneumonia in Wuhan, China. Jama. 2020;323(11):1061-9.

12. Huang C, Wang Y, Li X, Ren L, Zhao J, Hu Y, et al. Clinical features of patients infected with 2019 novel coronavirus in Wuhan, China. The lancet. 2020;395(10223):497-506.

13. Li Q, Guan X, Wu P, Wang X, Zhou L, Tong Y, et al. Early transmission dynamics in Wuhan, China, of novel coronavirus-infected pneumonia. New England Journal of Medicine. 2020.

14. Ko W-C, Rolain J-M, Lee N-Y, Chen P-L, Huang C-T, Lee P-I, et al. Remdesivir for SARS-CoV-2 pneumonia. Int J Antimicrob Agents. 2020.

15. Liu W, Zhang Q, Chen J, Xiang R, Song H, Shu S, et al. Detection of Covid-19 in children in early January 2020 in Wuhan, China. New England Journal of Medicine. 2020;382(14):1370-1.

16. Tagarro A, Epalza C, Santos M, Sanz-Santaeufemia FJ, Otheo E, Moraleda C, et al. Screening and severity of coronavirus disease 2019 (COVID-19) in children in Madrid, Spain. JAMA pediatrics. 2020.

17. Chow N, Fleming-Dutra K, Gierke R, Hall A, Hughes M, Pilishvili T, et al. Preliminary estimates of the prevalence of selected underlying health conditions among patients with coronavirus disease 2019United States, February 12-March 28, 2020. 2020.

18. Jahromi R, Pakravan HA, Saidi MS, Firoozabadi B. Primary stenosis progression versus secondary stenosis formation in the left coronary bifurcation: A mechanical point of view. Biocybernetics and Biomedical Engineering. 2019;39(1):188-98.

19. Doyen D, Moceri P, Ducreux D, Dellamonica J. Myocarditis in a patient with COVID-19: a cause of raised troponin and ECG changes. The Lancet. 2020;395(10235):1516.

20. McBride W, Lange RA, Hillis LD. Re-Stenosis after Successful Coronary Angioplasty. New England Journal of Medicine. 1988;318(26):1734-7.

21. Zeng J-H, Liu Y-X, Yuan J, Wang F-X, Wu W-B, Li J-X, et al. First case of COVID-19 complicated with fulminant myocarditis: a case report and insights. Infection. 2020:1. 
22. Kim I-C, Kim JY, Kim HA, Han S. COVID-19-related myocarditis in a 21-year-old female patient. European Heart Journal. 2020;41(19):1859-.

23. Robinson J, Hartling L, Vandermeer B, Sebastianski M, Klassen TP. Intravenous immunoglobulin for presumed viral myocarditis in children and adults. Cochrane Database of Systematic Reviews. 2020(8).

24. Amabile N, Fraisse A, Bouvenot J, Chetaille P, Ovaert C. Outcome of acute fulminant myocarditis in children. Heart. 2006;92(9):1269-73.

25. Duncan BW, Bohn DJ, Atz AM, French JW, Laussen PC, Wessel DL. Mechanical circulatory support for the treatment of children with acute fulminant myocarditis. The Journal of thoracic and cardiovascular surgery. 2001;122(3):440-8.

26. Martin AB, Webber S, Fricker FJ, Jaffe R, Demmler G, Kearney D, et al. Acute myocarditis. Rapid diagnosis by PCR in children. Circulation. 1994;90(1):330-9.

27. Li X, Xu S, Yu M, Wang K, Tao Y, Zhou Y, et al. Risk factors for severity and mortality in adult COVID19 inpatients in Wuhan. Journal of Allergy and Clinical Immunology. 2020.

28. Jahromi R, Avazpour A, Jahromi M, Alavi J. COVID-19 with positive bronchoalveolar lavage fluid but negative nasopharyngeal and oropharyngeal swabs: a case report and insights. Indian Journal of Case Reports. 2020:380-2.

29. Qiu H, Wu J, Hong L, Luo Y, Song Q, Chen D. Clinical and epidemiological features of 36 children with coronavirus disease 2019 (COVID-19) in Zhejiang, China: an observational cohort study. The Lancet Infectious Diseases. 2020.

30. Simon AK, Hollander GA, McMichael A. Evolution of the immune system in humans from infancy to old age. Proceedings of the Royal Society B: Biological Sciences. 2015;282(1821):20143085.

31. Jahromi R, Mogharab V, Jahromi H, Avazpour A. Synergistic effects of anionic surfactants on coronavirus (SARS-CoV-2) virucidal efficiency of sanitizing fluids to fight COVID-19. Food and Chemical Toxicology. 2020. 145, 111702.

32. Ludvigsson JF. Systematic review of COVID-19 in children shows milder cases and a better prognosis than adults. Acta Paediatrica. 2020;109(6):1088-95.

33. Riphagen S, Gomez X, Gonzalez-Martinez C, Wilkinson N, Theocharis P. Hyperinflammatory shock in children during COVID-19 pandemic. The Lancet. 2020;395(10237):1607-8.

34. Lee P-I, Hu Y-L, Chen P-Y, Huang Y-C, Hsueh P-R. Are children less susceptible to COVID-19? Journal of Microbiology, Immunology, and Infection. 2020. 